\title{
ANALISIS KEMAMPUAN BERPIKIR KRITIS SISWA SMA MATERI ALAT INDERA MELALUI MODEL PEMBELAJARAN INQUIRY PICTORIAL RIDDLE
}

\author{
Lesy Luzyawati \\ Universitas Wiralodra \\ e-mail: lesyahmed@gmail.com
}

\begin{abstract}
Abstrak
Penelitian ini bertujuan untuk mengetahui analisis kemampuan berpikir kritis siswa SMA pada materi alat indera melalui model pembelajaran inquiry pictorial riddle. Jenis penelitian yang digunakan adalah kuantitatif deskriptif, desain yang digunakan adalah PreExperimental Design dengan tipe One-Shot Case Study. Hasil penelitian menunjukkan kemampuan berpikir kritis siswa berbeda-beda. Hasil kemampuan berpikir kritis dari 32 siswa menunjukkan Hasil kemampuan berpikir kritis dari 32 siswa menunjukkan $50 \%$ siswa berada pada kategori sangat baik, 26,5\% berkategori baik, dan 23,5\% siswa berada pada kategori sedang. Pencapaian kelima indikator berpikir kritis dari seluruh siswa pun berbeda, dimana pencapaian indikator berpikir kritis memberi penjelasan sederhana memiliki persentase paling tinggi yaitu 90\% (sangat baik) dibanding indikator lainnya, indikator berpikir kritis membangun keterampilan dasar memiliki persentase $84 \%$ (baik), indikator berpikir kritis menyimpulkan memperoleh persentase $80 \%$ (baik), dan indikator memberi penjelasan lanjutan memperoleh persentase 60\% (sedang) dimana pencapaian indikator ini paling rendah dibandingkan indikator lainnya serta indikator mengatur strategi dan taktik dimana memperoleh persentase 73 (baik). Sehingga diperoleh rata-rata kemampuan berpikir kritis seluruh siswa di kelas XI MIPA 6 SMA Negeri 1 Sindang Indramayu yaitu $77 \%$ dengan kategori baik.
\end{abstract}

Kata kunci : Alat Indera, Kemampuan Berpikir Kritis, dan Model Pembelajaran Inquiry Pictorial Riddle

\begin{abstract}
This study aims to analyse the critical thinking skills of high school students on fivesenses material through the usage of inquiry pictorial riddle learning model. The type of the research used is descriptive quantitative with Pre-Experimental Design and type One-Shot Case Study. The results shows that the students' critical thinking ability were vary. Of 32 students, $50 \%$ of students can be classified into very good category, $26.5 \%$ into good category, and $23.5 \%$ students into medium category. The achievement on the five critical thinking indicators of all students were also different, in which the achievement of critical thinking indicator of giving the simplest explanation has the highest percentage of $90 \%$ (very good) compared to another indicators, building basic skill has $84 \%$ percentage (good), making conclusion $80 \%$ (good), and 60\% (medium) in giving further information, in which the achievement of this indicator is the lowest compared to another indicator. On indicator of setting strategy and tactics the percentage is 73 (good). Based on the statistical numbers above, the average thinking ability of all students in grade XI MIPA 6 SMA Negeri 1 Sindang Indramayu is $77 \%$ wich can be classified into good category.
\end{abstract}

Keywords: critical thinking skills, inquiry pictorial riddle learning model, and sensory equipment 


\section{PENDAHULUAN}

Proses pembelajaran Biologi merupakan salah satu bidang studi bagian sains yang bersifat logis dan kritis, hal ini untuk meningkatkan upaya dalam memajukan daya pikir manusia. Berpikir merupakan suatu kegiatan mental yang dialami seseorang bila mereka dihadapkan pada suatu masalah atau situasi yang harus dipecahkan. Salah satu tujuan pembelajaran biologi yaitu mengajarkan siswa bagaimana dapat berpikir secara kritis. Menurut Norris dan Ennis (2000, dalam Fisher 2009:4) memdefinisikan bahwa "berpikir kritis adalah pemikiran yang masuk akal dan reflektif yang berfokus untuk memutuskan apa yang mesti dipercaya atau dilakukan".

Farida \& Winarti (2013: 28) menyatakan bahwa "keterampilan berpikir kritis perlu diajarkan dalam pembelajaran sains". Hal ini sebagaimana dalam Peraturan Menteri Pendidikan Republik Indonesia nomor 41 tahun 2007 tentang standar proses untuk satuan pendidikan dasar dan menengah menyatakan keharusan mengembangkan keterampilan berpikir dalam proses pembelajaran yaitu pada tahap kegiatan inti, khususnya kegiatan elaborasi (BSNP, 2007:16). Konsekuensi dari aturan tersebut bahwa guru dituntut untuk dapat mengembangkan kemampuan berpikir, baik keterampilan berpikir logis, analisis maupun keterampilan berpikir kritis.

Problematika yang selama ini menghantui pendidikan adalah dalam hal menerapkan metode/model dalam proses pembelajaran. Kebanyakan guru masih menerapkan pembelajaran yang bersifat konvensional tidak mengacu terhadap kemampuan berpikir kritis siswa. Kurang kreatifnya guru dalam menggunakan model pembelajaran di kelas menyebabkan pelaksanaan pembelajaran cenderung monoton.

Hasil observasi sebelumnya di SMA Negeri 1 Sindang Indramayu, model/metode pembelajaran yang diterapkan ialah ceramah, diskusi, dandemonstrasi. Pembelajaran tersebut belum dapat melibatkan dan mengaktifkan siswa dalam pembelajaran, dan masih banyak siswa belum dapat mengolah keterampilan nalar, bertanya, dan analisisnya. Selain itu, ada faktor lain yang juga mempengaruhi kemampuan berpikir kritis siswa tidak terlatih, yaitu karena pada saat pembelajaran masih mengarah pada Teacher centered yang membuat siswa hanya menerima informasi dari seorang guru saja, sehingga menyebabkan kegiatan pembelajaran di kelas tampakbosan,jenuh,dankurang bersemangat.

Permasalahan tersebut dapat mengakibatkan tingkat berpikir kritis siswa rendah sehingga siswa tidak bisa menyelesaikan masalah dan menawarkan solusi serta siswa menjadi pribadi yang pasif dalam hal kurangnya kepercayaan diri, dan siswa cenderung salah mengartikan konsep-konsep pembelajaran. Jika dalam jangka waktu berkepanjangan permasalahan ini terus terjadi, maka hal ini akan mengakibatkan kemunduran mental bangsa dan akan berdampak buruk bagi masa depan mereka, seperti 
yang dikatakan oleh Wena (2012:53) bahwa "kemampuan berpikir sangat penting artinya bagi siswa dan masa depannya". Oleh karena itu, dalam proses belajar mengajar guru mempunyai tugas untuk mendorong, membimbing dan memberi fasilitas belajar bagi murid-murid untuk mencapai tujuan.

Guru dalam memilih dan memilah model pembelajaran ini sejalan dengan semangat reformasi pendidikan yang bergulir. Semangat reformasi menghendaki adanya perubahanperubahan mendasardalam sistem pembelajaran. Salah satunya dengan menggunakan model Inquiry Pictorial Riddle. Menurut Haryono (2012:109) bahwa "Inquiry pictorial riddle adalah salah satu teknik atau metode untuk mengembangkan motivasi dan minat peserta didik di dalam situasi kelompok kecil maupun besar. Gambar, peragaan, atau situasi yang sesungguhnya dapat digunakan untuk meningkatkan cara berpikir kritis dan kreatif peserta didik".

Model pembelajaran Pictorial Riddle sudah pernah diteliti dan hasilnya dapat meningkatkan kemampuan berpikir kritis siswa pada materi suhu dan kalor pada kelas $X$ SMA Negeri 1 Piyungan Bantul Yogyakarta (Khasanah, 2014). Rahmayani (2015) menerapkan model inquiry terbimbing dalam pembelajaran sehingga dapat meningkatkan berpikir kritis. Begitu pula dengan Sulistyani (2015) juga mengungkapkan hasil penelitiannya bahwa model pembelajaran Inquiry Pictorial Ridle dapat meningkatkan hasil belajar IPS siswa. Untuk itu, penulis memilih model pembelajaran inquiry pictorial ridle pembelajaran sebagai satu solusi permasalahan dari rendahnya kemampuan berpikir kritis siswa SMA dalam mata pelajaran Biologi. Perbedaan penelitian ini dengan penelitianpenelitian sebelumnya ialah materi pembelajaran yang dipilih yaitu konsep kelainan pada alat indera manusia.

Pemilihan materi kelainan alat indera merupakan salah satu materi yang membahas mengenai permasalahan sehari-hari. Melihat kondisi demikian perlu adanya penerapan model pembelajaran yang dapat memfasilitasi siswa untuk mengolah kemampuan berpikir kritis dalam menganalisis suatu masalah dan memberikan solusi untuk menunjang hasil belajar dan menjadikan kualitas pembelajaran optimal sehingga tujuan pembelajaran dapat tercapai.

\section{METODE}

Penelitian ini merupakan jenis penelitian deskriptif menggunakan pendekatan kuantitatif. Desain penelitian yang digunakan adalah Pre-Experimental Design dengan bentuk One-Shot Case Study.

Penelitian diawali dengan pelaksanaan pembelajaran menggunakan model Inquiry Pictorial Riddle. Siswa disajikan permasalahan kepada siswa berupa teka-teki gambar, melakukan mengidentifikasi masalah, melakukan pengamatan berdasarkan gambar riddle, 
merumuskan penjelasan dan melakukan tanya jawab. Pada saat proses pembelajaran tersebut dilakukan observasi untuk mengumpulkan data. Diakhir pembelajaran, siswa diberikan soal tes kemampuan berpikir kritis dalam bentuk essai.

Populasi pada penelitian ini adalah semua kelas XI MIPA di SMA Negeri 1 Sindang yang meliputi XI MIPA 1- XI MIPA 7 yang berjumlah 280 siswa. Sedangkan Sampel pada penelitian ini adalah XI MIPA 6 yang berjumlah 32 siswa. Teknik pengambilan sampel dilakukan dengan sampling purposive. Teknik sampel pada penelitian ini dengan pertimbangan kelas XI MIPA 6 sejumlah 32 siswa dianggap dapat mengikuti proses pembelajaran menggunakan model inquiry pictorial riddle atas saran guru mata pelajaran di SMA Negeri 1 Sindang Indramayu. Adapun penelitian dilaksanakan pada semester genap tahun ajaran 2016/2017.

Jenis instrumen yang digunakan dalam penelitian ini yaitu instrumen tes essai, dan lembar observasi. Tes yang diujicobakan berupa tes essai terdiri dari 10 butir soal yang sesuai dengan indikator berpikir kritis menurut Ennis (2000, dalam dalam Fisher 2009:2) dan indikator pemahaman Taksonomi Bloom revisi aspek kognitif C3, C4, C5. Soal diujicobakan pada kelas XI MIPA 2 dengan jumlah siswa 32 orang yang sebelumnya sudah mendapatkan materi alat indera. Bentuk tes essai ini adalah tes essai terbuka untuk mengetahui analisis kemampuan berpikir kritis siswa.Sedangkan untuk instrumen lembar observasi yang digunakan adalah observasi partisipatif moderat. Untuk memperoleh data hasil observasi, peneliti melibatkan 3 observer untuk menilai keterampilan berpikir kritis melalui pembelajaran inquiry pictorial riddle.

Untuk menghasilkan suatu tes yang baik, maka penulis memperhatikan tingkat validitas dan reliabilitas. validitas soal tes essai diujicobakan di kelas XII MIPA 5, kemudian divalidasi menggunakan rumus korelasi product moment dengan angka kasar kemudian uji kooefesien korelasi dengan uji t dengan tujuan untuk mengetahui signifikansi kooefesien tersebut.Dari 10 soal yang diujicobakan hanya 5 soal yang valid dan kelima soal tersebut digunakan sebagai instrumen.Pengujian reliabilitas dilakukan dengan internal consisten sekali saja, kemudian data yang diperoleh dianalisis dengan metode tertentu. pengujian reliabilitas yang dilakukan adalah pengujian reliabilitas untuk instrumen skor non diskrit dengan menggunakan rumus Alpha, hasilnya dinyatakan reliabel.

Teknik analisis data kemampuan berpikir kritis yang diperoleh melalui tes essai, berupa skor yang akan dianalisis secara statistik. Data penelitian diolah dengan menggunakan rumus persentase menurut Riduwan (2013:41) sebagai berikut, dengan kriteria ketercapaian sama dengan tabel kemampuan berpikir kritis. persentase rata-rata pencapaian kemampuan berpikir kritis (KBK) seluruh siswa dari hasil persentase pencapian setiap indikator untuk seluruh siswa dengan kriteria penafsiran skor (sangat baik, baik, sedang, buruk, dan sangat buruk), dengan kriteria penafsiran pada Tabel 1. 
Tabel 1. Kategori Kemampuan Berpikir Kritis Siswa pada Tes Essay

\begin{tabular}{ccc}
\hline No & Presentase & Kategori/aspek kualitas \\
\hline $\mathbf{1}$ & $81-100$ & Sangat baik \\
$\mathbf{2}$ & $61-80$ & Baik \\
$\mathbf{3}$ & $41-60$ & Sedang \\
$\mathbf{4}$ & $21-40$ & Buruk \\
$\mathbf{5}$ & $0-20$ & Buruk sekali \\
\hline & & (Riduwan, 2013:41)
\end{tabular}

\section{HASIL PENELITIAN DAN PEMBAHASAN}

Data dan hasil penelitian meliputi skor kemampuan berpikir kritis setiap siswa, Analisis kemampuan berpikir kritis kelompok per indikator dan hasil rata-rata persentase indikator kemampuan berpikir kritis seluruh siswa. Data tersebut diperoleh dari hasil tes essai berjumlah 5 soal dan lembar observasi yang telah diisi.

Hasil tes kemampuan berpikir kritis siswa dan hasil observasi dikelompokkan bedasarkan indikator berpikir kritis memberi penjelasan sederhana, membangun keterampilan dasar, menyimpulkan, memberi penjelasan lanjutan, dan mengatur strategi dan taktik. Untuk lebih jelasnya dapat dilihat pada Tabel 2.

Tabel 2. Hasil Tes Kemampuan Berpikir Kritis dan Observasi Berpikir Kritis

\begin{tabular}{|c|c|c|c|c|c|}
\hline \multirow[t]{2}{*}{ No } & \multirow[t]{2}{*}{ Indikator } & \multicolumn{2}{|c|}{ Hasil Tes } & \multicolumn{2}{|c|}{ Hasil Observasi } \\
\hline & & $\begin{array}{l}\text { Persentase } \\
\text { per indikator }\end{array}$ & Kategori & $\begin{array}{l}\text { Persentase } \\
\text { per indikator }\end{array}$ & Kategori \\
\hline 1 & $\begin{array}{l}\text { Memberi } \\
\text { Penjelasan } \\
\text { Sederhana }\end{array}$ & $90 \%$ & Sangat Baik & $91 \%$ & Sangat Baik \\
\hline 2 & $\begin{array}{l}\text { Membangun } \\
\text { Keterampilan } \\
\text { Dasar }\end{array}$ & $83 \%$ & Sangat Baik & $85 \%$ & Sangat Baik \\
\hline 3 & Menyimpulkan & $78 \%$ & Baik & $81 \%$ & Sangat Baik \\
\hline 4 & $\begin{array}{l}\text { Memberi } \\
\text { Penjelasan } \\
\text { Lanjutan }\end{array}$ & $61 \%$ & Sedang & $60 \%$ & Sedang \\
\hline 5 & $\begin{array}{l}\text { Mengatur } \\
\text { Strategi dan } \\
\text { Taktik }\end{array}$ & $72 \%$ & Baik & $75 \%$ & Baik \\
\hline Rer: & & $77 \%$ & & $78 \%$ & \\
\hline
\end{tabular}

Setelah melakukan pembelajaran, pengumpulan data serta analisis data tes dan observasi kemampuan berpikir kritis siswa, maka di peroleh hasil kemampuan berpikir kritis siswa di SMA Negeri 1 Sindang Indramayu di kelas XI MIPA 6 dengan kategori sangat baik, baik, dan sedang. Kategori tersebut mengacu pada kategori kemampuan berpikir kritis menurut Riduwan (2013:41). Untuk lebih jelasnya dapat dilihat pada Gambar 1. 


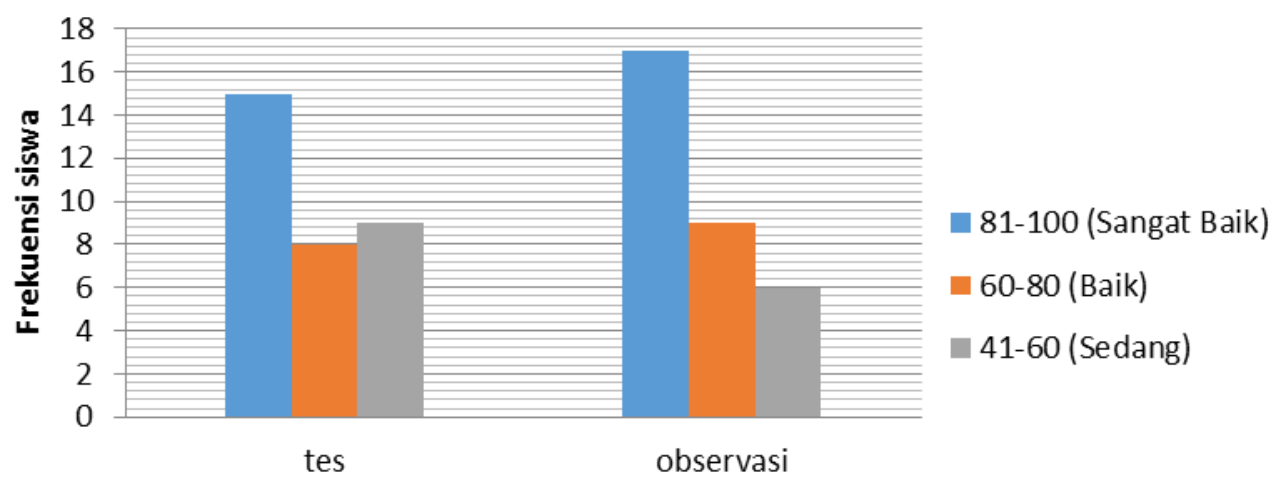

Gambar 1. Diagram batang frekuensi perolehan hasil skor tes dan observasi kemampuan berpikir kritis siswa di SMA Negeri 1 Sindang Indramayu

Gambar 1 menunjukkan frekuensi persentase hasil tes dan observasi siswa pada hasil penelitian Gambar 1, dapat dijelaskan bahwa hasil tes menunjukkan dari 32 siswa, terdapat 15 siswa yang memiliki kemampuan berpikir kritis sangat baik dan dari 32 siswa dari hasil observasi menunjukkan 17 siswa yang memiliki kemampuan berpikir kritis sangat baik. Hal ini menunjukkan siswa-siswa tersebut sangat mampu mengikuti kegiatan pembelajaran dan dapat memahami materi alat indera pada pokok bahasan kelainan sistem indera dengan sangat baik yang dapat dilihat dari kemampuan peserta didik dalam menjawab soal dimana mereka dapat menganalisis lebih dari satu kemungkinan dari gambar teka-teki atau suatu informasi mengenai kelainan sistem indera yang diberikan. Hal ini sesuai dengan pendapat Dawey (dalam Fisher, 2009:2) mendefinisikan berpikir kritis sebagai berpikir reflektif yaitu "pertimbangan yang aktif, persistent (terus-menerus), dan teliti mengenai sebuah keyakinan atau bentuk pengetahuan yang diterima begitu saja dipandang dari sudut alasan-alasan yang mendukungnya dan kesimpulan-kesimpulan lanjutan yang menjadi kecenderungannya".

Siswa yang memiliki kemampuan berpikir kritis baik yaitu berjumlah 8 orang dari hasil tes dan 9 orang dari hasil observasi, hal ini dibuktikan siswa tersebut mampu memahami materi kelainan sistem indera dan mampu menganalisis informasi kelainan sistem indera , mengevaluasi penyebab dan cara pencegahan atau pengobatan kelainan sistem indera yang terjadi. Siswa tersebut juga aktif dalam proses pembelajaran dan terjasi interaksi yang baik antara pendidik maupun sesama peserta didik. Hal tersebut sesuai dengan pendapat Ferdinan (2009) menyatakan bahwa "salah satu faktor yang dapat mempengaruhi kemampuan berpikir kritis adalah interaksi antara pengajar dan siswa". Siswa memerlukan suasana pembelajaran yang dapat memberikan kebebesan dan rasa aman bagi siswa untuk mengekspresikan pendapat dan keputusannya selama proses pembelajaran (Suhmaji, 2014).

Siswa yang memiliki kemampuan berpikir kritis dengan kategori sedang dari 32 siswa, dari hasil tes yaitu 9 siswa dan dari hasil observasi 6 orang, Artinya, siswatersebut cukup 
memahami materi kelainan sistem indera. Hal tersebut dapat dibuktikan dengan cukup mampu menjawab soal kemampuan berpikir kritis tentang menganalisis informasi yang disajikan mengenai kelainan dan mengevaluasi penyebab dan pencegahannya. Selain itu, siswa tersebut kurang minat dan kurang aktif dalam mengikuti pembelajaran dan pada saat diskusi sehingga kurang mencapai tujuan pembelajaran yang telah ditetapkan. Hal tersebut sesuai dengan pendapat Rusman (2014) yang menyatakan bahwa "selain mempengaruhi berpikir kritis, minat siswa juga mempengaruhi tercapainya tujuan pembelajaran".

Inquiry Pictorial Riddle sangat membantu siswa untuk berpikir kritis dalam proses belajar mengajar dan memahami konsep-konsep dari pembelajaran dapat meningkatkan motivasi belajar siswa yang memungkinkan memahami masalah-masalah dikehidupan sehari-hari. Hal ini sejalan dengan Mayasa (dalam Sulistyani (2015:25), kelebihan model Inquiry Pictorial Riddle yaitu: "1) Membuat siswa lebih memahami konsep-konsep dasar dan dapat mendorong siswa untuk mengemukakan gagasannya. 2) Melalui teka-teki gambar, materi yang diterima oleh siswa lebih tahan lama. 3) Mendorong siswa untuk berpikir kritis, dan kreatif. 4) Mendorong siswa untuk dapat berpikir intuitif dan merumuskan hipotesisnya sendiri. 5) Meningkatkan motivasi belajar siswa. 6) Siswa tidak hanya belajar tentang konsep, tetapi siswa juga mengalami proses belajar menemukan konsep tersebut. 7) Meningkatkan rasa tanggung jawab dan komunikasi sosial siswa. 8) Dapat memperkaya dan memperdalam materi yang dipelajari sehingga materi dapat bertahan lama di dalam ingatan".

Tidak semua siswa siap untuk menghadapi masalah-masalah yang akan mereka hadapi dalam Pembelajaran Inquiry pictorial riddle dikarenakan sebagian siswa terbiasa belajar dengan hanya menerima konsep-konsep pembelajaran dari gurunya saja sehingga mereka kesulitan dalam mencari sendiri konsep-konsep pembelajaran. Hal ini sejalan dengan pendapat Mayasa (dalam Sulistyani, 2015:26), kekurangan model inquiry pictorial riddle yaitu:"1) Siswa yang terbiasa belajar dengan hanya menerima informasi dari guru akan kesulitan jika dituntut untuk berpikir sendiri. 2) Guru dituntut mengubah gaya mengajarnya yang awalnya sebagai pemberi atau penyaji informasi, menjadi fasilitator, motivator, dan pembimbing siswa dalam belajar. 3) Penggunaan model ini pada kelas besar serta jumlah guru yang terbatas membuat pembelajaran kurang optimal. 4) Pemecahan masalah dapat bersifat mekanistis, formalitas, dan membosankan".

Data pada Tabel 2 menunjukkan bahwa indikator berpikir kritis yang dianalisis yaitu berjumlah 5 indikator yaitu memberikan penjelasan sederhana, membangun keterampilan dasar, menyimpulkan, memberi penjelasan lanjutan, dan mengatur strategi dan taktik. Hasil persentase setiap indikator kemampuan berpikir kitus berasal dari hasil perhitungan persentase hasil tes dan observasi. Untuk lebih jelasnya dapat di lihat pada Gambar 2. 


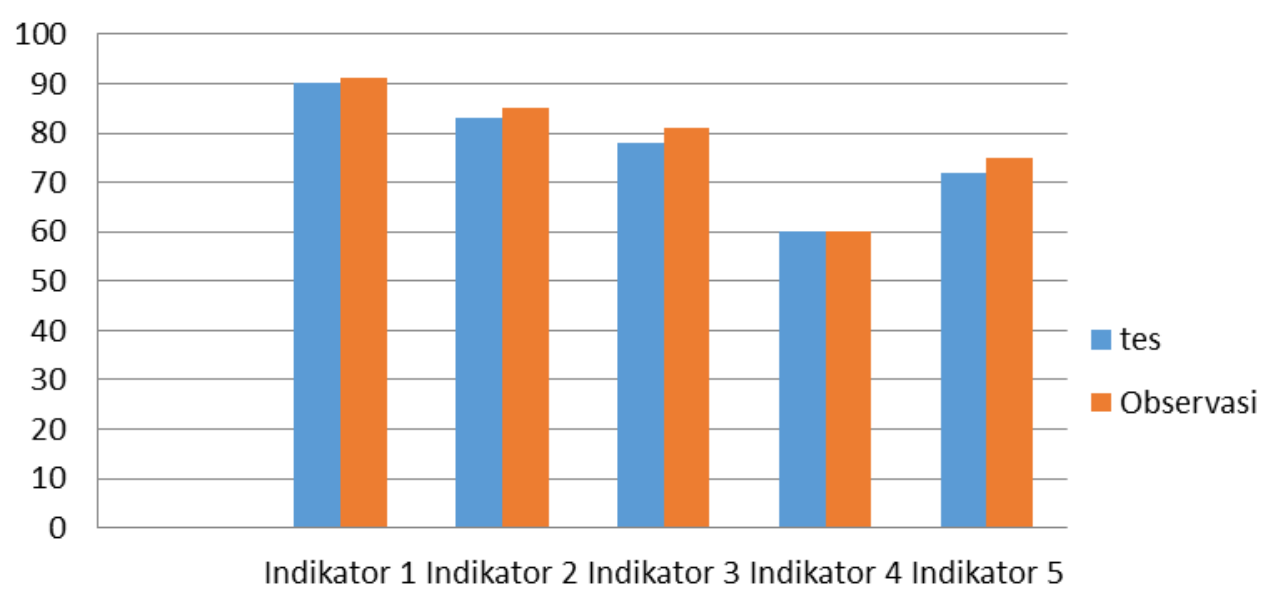

Gambar 2. Diagram presentase tes \& lembar observasi kemampuan berpikir kritis pada setiap indikator

Gambar 2 menjelaskan persentase setiap indikator Kemampuan berpikir Kritis (KBK) dari hasil tes dan observasi. Diagram yang berwarna biru menunjukkan persentase hasil tes, sedangkan diagram yang bewarna merah menunjukkan persentase hasil observasi. Hasil observasi persentasenya lebih tinggi dibandingkan hasil tes namun tidak terpaut jauh.

Hal tersebut terjadi karena pada saat diskusi terlihat sebagian besar siswa memperlihatkan kemampuan mereka dalam berdiskusi dan dapat menguasai konsep dengan baik, dan cenderung siswa lebih aktif dan kritis dalam bertanya, berargumen, hingga mengomunikasikan hasil diskusi didepan kelas. Namun pada saat mengerjakan tes essai sebagian siswa salah memahami pertanyaan dan kurangnya memberikan penjelasan mengenai jawaban mereka dengan mengaitkan konsep-konsep kelainan sistem indera. Sedangkan pencapaian indikator yang paling tinggi adalah pada indikator pertama yaitu memberi penjelasan sederhana, dan persentase paling rendah adalah indikator ke 4 yaitu memberi penjelasan lanjutan. Untuk lebih jelasnya dapat dilihat pada Gambar 3. 


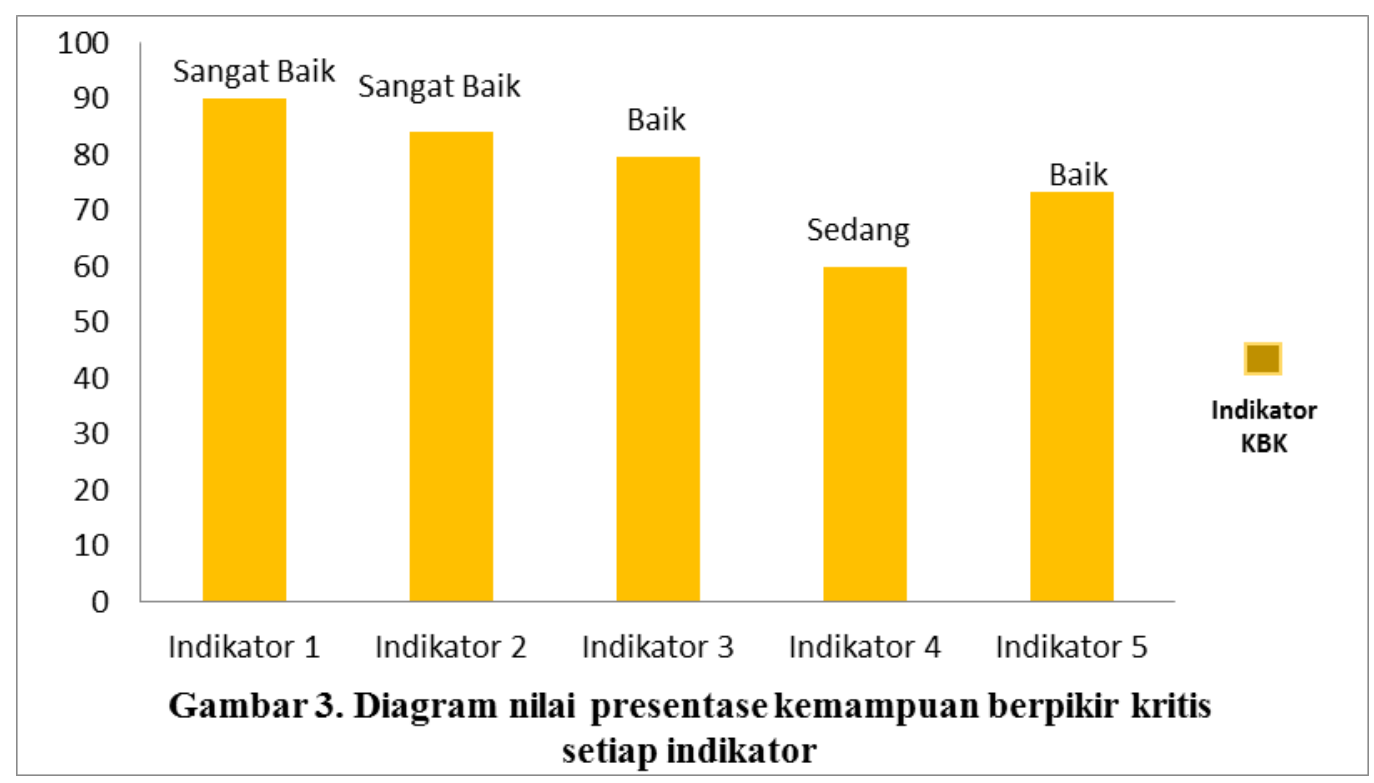

Hasil persentase indikator $1 \mathrm{KBK}$ memberi penjelasan sederhana yaitu 90\% dengan kategori sangat baik, persentase indikator 2 KBK membangun keterampilan dasar yaitu $84 \%$ dengan kategori sangat baik, persentase indikator 3 KBK menyimpulkan yaitu $80 \%$ dengan kategori baik, dan persentase indikator 4 KBK memberi penjelasan lanjutan yaitu $60 \%$ dengan kategori sedang serta persentase indikator $5 \mathrm{KBK}$ mengatur strategi dan taktik yaitu 73\% dengan kategori baik. Untuk lebih jelasnya lihat Gambar 1.3

Gambar 3 menunjukkan pencapaian indikator KBK seluruh siswa menunjukkan bahwa indikator KBK memberi penjelasan sederhana memiliki persentase paling tinggi dibanding indikator lainnya yaitu 90\% dengan kategori sangat baik, Hal tersebut terjadi karena pada saat proses pembelajaran siswa dapat berdiskusi, dan melakukan analisis inquiry melalui tanya jawab serta memberikan penjelasan sesuai dengan konsep yang telah mereka pelajari dengan sangat baik serta hasil tes yang memperkuat data observasi dengan pencapaian sangat baik pula. Indikator KBK memberi penjelasan lanjutan memiliki persentase paling rendah dibanding indikator lainnya yaitu $60 \%$ dengan kategori sedang, hal tersebut terjadi karena siswa kurang memahami asumsi atau informasi yang diberikan mengenai kelainan sistem indera, dan belum bisa memberikan penjelasan lanjutan mengenai suatu kejadian sehingga siswa kurang tepat dalam memberikan tanggapan terhadap informasi atau asumsi tersebut.

Gambar 3 menunjukkanbahwa pada indikator memberikan penjelasan sederhana, rata-rata pencapaian pada indikator ini dari seluruh siswa yaitu $90 \%$, termasuk kategori sangat baik. Rata-rata persentase tersebut diperoleh dari hasil persentase hasil tes dan hasil observasi. Gambar 2 menunjukkan hasil tes lebih rendah dibanding hasil observasi namun tidak terpaut jauh. Hal tersebut terjadi karena dari hasil observasi pencapaian indikator ini $91 \%$ (sangat baik) karena sebagian besar siswa dapat memberikan penjelasan mengenai kelainan sistem indera dan dapat berdiskusi serta melakukan analisis inquiry 
melalui tanya jawab sesuai konsep yang telah dipelajari. Analisis inquiry melalui tanya jawab tersebut terdapat pada sintak terakhir dari pembelajaran inquiry pictorial riddle. Pada tahapan tersebut siswa melakukan proses tanya jawab antar siswa mengenai kelainan sistem indera dengan sangat baik, dimana mereka saling melemparkan pertanyaan yang bersifat analisis dan memberikan jawaban atau penjelasan secara logis sesuai dengan konsep kelainan sistem indera. Hal ini sejalan dengan Johnson (2014:185) mengartikan seseorang yang memiliki kemampuan berpikir kritis adalah "kemampuan untuk mengatakan sesuatu dengan penuh percaya diri, memiliki ide yang bagus karena bedasarkan alasan yang logis." Hasil tes juga memperkuat data observasi dengan pencapaian sangat baik pula yaitu 90\% dimana siswa sudah sangat baik dalam menjelaskan fakta-fakta yang diperoleh dari hasil analisis suatu informasi atau gambar.

Indikator berpikir kritis membangun keterampilan dasar dari seluruh siswa yaitu $84 \%$ dengan kategori sangat baik. Persentase hasil tes tidak jauh berbeda dengan observasi dimana keduanya berkategori sangat baik. Hal tersebut terjadi karena dari hasil observasi ketercapaian indikator ini mencapai 85\% (sangat baik), dimana siswa dapat berdiskusi, dan membangun keterampilan dasar mereka dalam menyusun riddle dan memecahkan teka-teki riddle tersebut. Pada proses pembelajaran, penyusunan riddle dan proses analisis ada pada sintak pertama dalam model inquiry pictorial riddle. Siswa disediakan suatu riddle atau gambar teka-teki dan mereka harus menyusun dan menganalisis riddle tersebut sehingga mereka bisa menemukan sendiri konsep pembelajaran mengenai kelainan sistem indera. Hal ini sejalan dengan Haryono (2012:109) "Inquiry pictorial riddle adalah salah satu model untuk mengembangkan motivasi dan minat peserta didik di dalam situasi kelompok kecil maupun besar. Gambar, peragaan, atau situasi yang sesungguhnya dapat digunakan untuk meningkatkan cara berpikir kritis dan kreatif peserta didik. Suatu riddle biasanya berupa gambar di papan tulis, papan poster, atau diproyeksikan, kemudian guru mengajukan pertanyaan yang berkaitan dengan riddle tersebut".

Persentase pencapaian indikator berpikir kritis menyimpulkan dari seluruh siswa yaitu $80 \%$ dengan kategori baik. Hal tersebut terjadi karena dari hasil observasi ketercapaian indikator ini mencapai $81 \%$ (sangat baik) dimana siswa dapat menyimpulkan secara sistematis dan sesuai dengan konsep yang ada. Hal tersebut dikarenakan mereka dapat melakukan proses identifikasi riddle dan merumuskan penjelasan terhadap ridlle atau informasi dengan sangat baik pula. Dengan melakukan proses pengumpulan data secara baik dan sistematis, dengan begitu mereka dapat memutuskan untuk membuat simpulan secara sistematis dan sesuai konsep bedasarkan hasil pengumpulan data yang telah mereka lakukan. Hal ini sejalan dengan Ennis (2000) mendefinisikan bahwa "berpikir kritis adalah pemikiran yang masuk akal dan reflektif yang berfokus untuk memutuskan apa 
yang dipercaya atau dilakukan". Sedangkan dari hasil tes dengan persentase $78 \%$ (baik) Sebagian siswa sudah baik dalam menyimpulkan suatu kejadian dengan mengaitkan dengan konsep yang ada, namun ada beberapa siswa juga yang masih ada yang menyimpulkan secara umum dan belum sesuai dengan konsep yang dipelajari.

Indikator berpikir kritis memberikan penjelasan lanjutan hanya mencapai $60 \%$ (sedang). Persentase indikator ini paling rendah dibanding indikator lainnya dimana hasil tes dan observasi masing-masing memperoleh persentase $60 \%$. Hal tersebut dikarenakan dari hasil observasi, terlihat siswa belum mampu memberi penjelasan lanjutan atau tanggapan lanjutan mengenai suatu informasi yang diberikan. Pada saat proses pembelajaran, model inquiry pictorial riddle sebenarnya sudah memfasilitasi siswa untuk dapat mencapai indikator memberikan penjelasan lanjutan. Salah satunya yaitu sintak yang mengharuskan siswa untuk dapat merumuskan penjelasan terhadap informasi atau riddle dan melakukan analisis inquiry melalui tanya jawab. Akan tetapi, banyak hal yang menjadi faktor rendahnya ketercapaian indikator ini dibanding indikator lainnya yaitu kurangnya memahami isi soal, masih kesulitan dalam menganalisis dan mengevaluasi informasi, dan banyak siswa yang terbiasa belajar dengan hanya menerima informasi dari guru, sehingga ketika mereka dihadapkan untuk memberi penjelasan lanjutan terhadap suatu permasalahan, sebagian besar siswa mengalami kesulitan. Hal ini sesuai dengan Mayasa (dalam Sulistyani, 2015:26), bahwa salah satu kelemahan model ini "siswa yang terbiasa belajar dengan hanya menerima informasi dari guru akan kesulitan jika dituntut untuk berpikir sendiri".

Memberi penjelasan lanjutan dalam hal ini yaitu mereka hanya bisa menjelaskan setiap konsep secara baik, namun jika dihadapkan suatu permasalahan yang menuntut mereka untuk mengaitkan beberapa konsep tersebut sebagian siswa masih mengalami kesulitan. Hasil observasi juga diperkuat dari hasil tes. Dimana dari jawaban siswa belum bisa menanggapi dengan benar terhadap asumsi/informasi yang diberikan, dan belum bisa memberikan penjelasan lanjutan mengenai informasi tersebut. Dilihat dari hasil tes dimana mereka salah dalam memberikan penjelasan lanjutan mengenai informasi kelainan sistem indera.

Indikator berpikir kritis yang terakhir yaitu mengatur strategi dan taktik. Rata-rata persentasenyahanya mencapai $74 \%$ (baik). Hal tersebut diperjelas dari hasil persentase observasi yaitu 75\% (baik) dan hasil tes memperoleh persentase $72 \%$ (baik). Proses pembelajaran dengan menggunakan model inquiry pictorial riddle sudah memfasilitasi siswa agar dapat memberikan langkah-langkah pencegahan penyakit yaitu merumuskan langkah-langkah pencegahan penyakit sistem indera. Dari hasil observasi siswa sudah baik memberikan langkah-langkah pencegahan terhadap suatu penyakit, namun ada pula yang hanya memberikan langkah-langkah pencegahan secara umum saja. Hasil tes yang 
memperkuat data observasi dengan pencapaian yang baik pula dengan memberikan lebih dari tiga tindakan pencegahan namun ada beberapa siswa dari hasil tes mereka hanya memberikan dua atau satu tindakan pencegahan kelainan sistem indera saja sehingga hasil tes tidak begitu besar dibanding hasil observasinya.

Kemampuan berpikir kritis setiap siswa berbeda-beda dimana ada yang berkategori sangat baik, baik dan sedang. Pencapaian kelima indikator berpikir kritis pun berbeda, dimana indikator berpikir kritis memberi penjelasan sederhana memiliki persentase paling tinggi yaitu 90\% (sangat baik) dibanding indikator lainnya, indikator berpikir kritis membangun keterampilan dasar memiliki persentase 84\% (baik), indikator berpikir kritis menyimpulkan memperoleh persentase $80 \%$ (baik), dan indikator memberi penjelasan lanjutan memperoleh persentase $60 \%$ (sedang) dimana pencapaian indikator ini paling rendah dibandingkan indikator lainnya serta indikator mengatur strategi dan taktik dimana memperoleh persentase $73 \%$ (baik).

Indikator memberi penjelasan lanjutan memiliki persentase paling rendah karena siswa yang mengalami kesulitan untuk memberi penjelasan lanjutan dimana banyak siswa yang terbiasa belajar dengan hanya menerima informasi dari guru, sehingga ketika mereka dihadapkan untuk memberi penjelasan lanjutan terhadap suatu permasalahan, sebagian besar siswa mengalami kesulitan. Hal tersebut juga terjadi karena kelemahan model inquiry pictorial riddle ini yaitu siswa yang terbiasa belajar dengan hanya menerima informasi dari guru akan kesulitan jika dituntut untuk berpikir sendiri.

\section{SIMPULAN}

Hasil penelitian dan analisis dapat disimpulkan bahwa kemampuan berpikir kritis siswa pada materi alat indera melalui model pembelajaran inquiry pictorial riddle di kelas XI MIPA 6 SMA Negeri 1 Sindang Indramayu diperoleh data kemampuan berpikir kritis siswa yang berbeda-beda. Hasil kemampuan berpikir kritis dari 32 siswa menunjukkan $50 \%$ siswa berada pada kategori sangat baik, $26,5 \%$ berkategori baik, dan $23,5 \%$ siswa berada pada kategori sedang.

Pencapaian kelima indikator berpikir kritis siswa pun berbeda, dimana pencapaian indikator berpikir kritis memberi penjelasan sederhana memiliki persentase paling tinggi yaitu $90 \%$ (sangat baik) dibanding indikator lainnya, indikator berpikir kritis membangun keterampilan dasar memiliki persentase $84 \%$ (baik), indikator berpikir kritis menyimpulkan memperoleh persentase $80 \%$ (baik), dan indikator memberi penjelasan lanjutan memperoleh persentase $60 \%$ (sedang) dimana pencapaian indikator ini paling rendah dibandingkan indikator lainnya serta indikator mengatur strategi dan taktik dimana memperoleh persentase 73 (baik). Sehingga diperoleh rata-rata kemampuan berpikir kritis 
seluruh siswa di kelas XI MIPA 6 SMA Negeri 1 Sindang Indramayu yaitu 77\% dengan kategori baik.

\section{DAFTAR PUSTAKA}

Ennis, R. H. 2011. An outline of goals for a critical thinking curriculum and its assessment. 2002.

Farida dan Winarti. 2008. Pengaruh Model Pembelajaran Berbasis Meningkatkan Keterampilan Berpikir Kritis Siswa Sekolah Dasar.Jurnal Kaunia, (9):2.

Fisher, A. 2009. Berpikir Kritis Sebuah Pengantar. Jakarta: Erlangga, 4.

Haryono. 2012. Model Pembelajaran. Bandung: Alfabeta.

Johnson.B. 2014. Critical Thingking. Jakarta: Erlangga.

Khazanah, B. N. 2014. Efektivitas Model Pembelajaran Inkuiri Tipe Pictorial Riddle dengan Konten Integrasi Interkoneksi Pada Materi Suhu dan Kalor terhadap Kemampuan Berpikir Kritis Siswa Kelas X SMA Negeri 1 Piyungan. Skripsi: Universitas Islam Negeri Sunan Kalijaga Yogyakarta.

Riduwan. 2013. Dasar-dasar Statistik. Bandung: Alfabeta.

Rusman. 2014. Model Pembelajaran Edisi kedua. Jakarta: Raja Grafindo Persada.

Suhmaji. 2014. Variasi Konstruk dalam pembelajaran Matematika Jurnal Kaunia, (9): 3.

Sulistyani, Ratih. 2015. Kefektifan Model Pictorial Riddle dalam Ilmu Pengetahuan Sosial Kelas III Sekolah Dasar Negeri 1 Karangmanayar Kabupaten Purbalingga. Skripsi Universitas Negeri Semarang.

Wena, M. 2012. Strategi Pembelajan Inovatif Kontemporer. Jakarta: Bumi Aksara. 